\title{
Effects of Calcium Levels and Limestone Particle Size on The Egg Quality of Semi-Heavy Layers in Their Second Production Cycle
}

\section{Author(s)}

Pizzolante CC

Saldanha ESPB

Laganá C

Kakimoto SK

Togashi CK

Pesquisadores Científicos da Agência Paulista de Tecnologia dos Agronegócios Regional (APTA) da Secretaria de Agricultura e Abastecimento do Estado de São Paulo (SAA).

\section{Mail Address}

Agência Paulista de Tecnologia dos Agronegócios Regional (APTA)

Caixa Postal 09

17.380-000. Brotas, SP, Brasil

E-mail: ccp@apta.sp.gov.br

\section{Keywords}

Eggs, eggshell quality, layers, levels, minerals

\section{ABSTRACT}

A 112-day trial was carried out to evaluate the effect of dietary calcium level and limestone particle size on the egg quality of $288 \mathrm{Hy}-$ Line Brown semi-heavy layers, with 83 weeks of age at the beginning of the experiment. A completely randomized experimental design was applied in a $2 \times 3$ factorial arrangement, with two dietary calcium levels (3.5 and 4.0\%) e three limestone particle size compositions (100\% fine limestone (FL), with $0.185 \mathrm{~mm} ; 30 \%$ coarse limestone $(\mathrm{CL})$, with $2.83 \mathrm{~mm}$, $+70 \% \mathrm{FL}$, with $0.185 \mathrm{~mm}$; and $50 \% \mathrm{CL}$, with $2.83 \mathrm{~mm}$, $+50 \% \mathrm{FL}$, with $0.185 \mathrm{~mm}$ ), with six replicates of eight birds each. Mean geometric diameter and in-vitro solubility of the limestone sources were, respectively, $0.185 \mathrm{~mm}$ and $18.7 \%$ for the fine limestone, and $2.83 \mathrm{~mm}$ and $10.5 \%$ for the coarse limestone. At the end of each 28 -day period, 72 eggs per treatment were used to determine egg specific gravity, yolk percentage, albumen percentage, eggshell percentage, yolk index, Haugh units, eggshell thickness, and eggshell breaking strength. There was no influence of the treatments on the evaluated parameters. It was concluded that feeding the level of $3.5 \%$ calcium usually recommended for layers in their first laying cycle, and the substitution of up to $50 \%$ fine limestone by coarse limestone in the feed of semiheavy commercial Hy-Line Brown layers in their second laying cycle can be applied with no impairment of egg quality.

\section{INTRODUCTION}

From the commercial perspective, the main function of the eggshell is of a package to protect the noble content of the egg (yolk and albumen) against losses and environmental aggression. The eggshell must be strong enough to resist the processes of lay, collection, grading, and transport, reaching the final consumer intact (Kussakawa et al., 1998).

Egg formation is a dynamic biological process that takes 24 to 36 hours, out of which 20 are required to form the eggshell after the egg reaches the eggshell gland (Swenson \& Reece, 1996). Eggshell defects include cracks, deformities, and irregular calcium deposition, in addition to invisible microbial contamination, resulting in economic losses.

Modern layer breeds have high egg production and low body weight in the first laying cycle. Second-cycle layers produce large and extralarge eggs, and present a higher percentage of thin eggshells due to disorders associated to calcium and vitamin $\mathrm{D}_{3}$ metabolism (Elaroussi et al., 1994).

Swanson \& Johnson (1973) reported that the larger the egg, the higher the probability of breaking, and that, as layers age, they lay larger eggs with lower eggshell calcium deposition, which decreases eggshell quality. 


\section{Pizzolante CC, Saldanha ESPB, Laganá C, Kakimoto SK, Togashi CK}

Mazzuco \& Hester (2005) explained that, with aging, hormones that are essential for reproduction, such estrogens, and their receptors decline, resulting in lower calcium absorption capacity by the gastrointestinal tract and renal tubules, as well as lower calcium transference from the uterus for eggshell formation. Thinner eggshells and simultaneous increase tibial mineralization are also observed, indicating failure in the mechanisms in calcium mobilization by layers at the end of lay.

Laying birds have high calcium requirements for bone maintenance and eggshell deposition, which are supplied by adequate and available calcium dietary sources. The knowledge calcium requirements for eggshell formation is essential, and the levels required after molting recommended in literature are still controversial (Rodrigues, 1995). Excessive dietary calcium interferes with the availability of other minerals, such as phosphorus, magnesium, manganese, and zinc (Borges, 1999). Studies on optimal calcium levels in layer diets are economically important, contributing to minimize broken eggshell percentage, production costs, and environmental impacts (Oliveira et al., 2002).

Several studies have been carried out to evaluate calcium sources, particle size, and solubility (Bertechini \& Fassani, 2001, Ito, 2002, Jardim Filho et al., 2005a, Geraldo et al., 2006). The results indicate that calcium must be supplemented with sources that have larger particles sizes and are less dusty as compared to standard limestone, particularly during the final stage of the laying cycle, to improve eggshell quality and the skeleton of modern layers.

Roland (1986), quoted by Faria et al. (2000), published a review on this subject, comparing 44 studies published between 1921 and 1985. That author verified that most results show that replacement of fine particles of calcium carbonate by coarse particles (oyster shell meal or limestone) improve eggshell quality. Coarser particles are efficient when layer are fed inadequate calcium levels or are exposed to factors that reduce its utilization. Therefore, coarser particles can be recommended under field conditions, provided their solubility is taken into account.

Rao \& Roland (1990) fed layers with 3.0, 4.5, and $6.0 \%$ limestone with two different particle sizes (fine limestone between 0.5 and $0.8 \mathrm{~mm}$, and coarse limestone between 2 and $4 \mathrm{~mm}$ ), and observed lower calcium solubility and retention when calcium levels increased. Layers fed coarse limestone presented higher calcium retention, showing that particle size and calcium level influence calcium solubility in the digestive tract.
Effects of Calcium Levels and Limestone Particle Size on The Egg Quality of Semi-Heavy Layers in Their Second Production Cycle

Roland (1984), Leeson \& Summers (1997), Miles (2000), and Bertechini (2006) showed that oyster shell in coarse particles improved eggshell quality due to its lower solubility and slow release during the night, when eggshell is formed.

Cheng \& Coon (1990a) evaluated different limestone sources, dietary levels, and particle sizes, and concluded that the applied treatments did not affect egg production or weight, but influenced eggshell quality. Those authors suggested mixing limestone with different particle sizes to achieve optimal solubility. Rao et al. (1992) recommended limestone particle diameters larger than $1.0 \mathrm{~mm}$. On the other hand, Murata (1995) fed $3.75,4.15$, or $4.55 \%$ calcium levels to 57 -weekold layers, and did not observe significant differences in egg production, egg loss percentage, egg weight, breaking strength, eggshell percentage and thickness, or apparent egg density when $0,25,50,75$, and $100 \%$ powdered limestone was replaced by granulated limestone.

Faria et al. (2000) studied feeding systems and oyster shell supplementation in commercial layers, and observed that birds fed predominantly during the night presented worse performance and there was no benefits in terms of eggshell quality.

This study aimed at evaluating the effects of calcium levels and limestone particle size composition (fine, coarse, and combinations) in the diet of Hy-Line Brown commercial layers in their second laying cycle on eggshell quality.

\section{MATERIAL AND METHODS}

The experiment was carried out at the facilities of the Research and Development Unit of Brotas, Development Decentralization Department, Agribusiness Technology Agency of São Paulo, Brazil. A total number of 288 Hy-Line Brown commercial layers, with 83 weeks of age at the beginning of the experiment were used. Birds were distributed in 36 cages $(1.00 \mathrm{~m}$ long $\times 0.45 \mathrm{~m}$ deep $\times 0.40 \mathrm{~m}$ high) with a $0.50 \mathrm{~m}$ internal partition to allow housing eight birds per cage. Each cage was equipped with a cup drinker and a trough feeder place in front of the cage.

The experimental diets (Table 1) were based on corn and soybean meal, considering the raw material composition established by Rostagno et al. (2000).

Birds were submitted to conventional force molting. First, they were fasted for 14 days until they lost 25$28 \%$ of their live weight. Water was supplied ad libitum, and feed offer was gradually increased to 30 , 


\section{Pizzolante CC, Saldanha ESPB, Laganá C, Kakimoto SK, Togashi CK}

Effects of Calcium Levels and Limestone Particle Size on The Egg Quality of Semi-Heavy Layers in Their Second Production Cycle
60 , and $90 \mathrm{~g}$ feed/bird/day on the first, second, and third week, respectively. Birds were then fed every other day for five days, and then received a production feed for two days and were fasted for five days, completing 31 days of the molting period. Average bird weight at the beginning and the end of molting was $1740 \mathrm{~g}$ and $1270 \mathrm{~g}$, respectively, with $27.01 \%$ live weight loss.

\begin{tabular}{|c|c|c|}
\hline \multirow[t]{2}{*}{ Ingredients (\%) } & \multicolumn{2}{|c|}{ Calcium levels (\%) } \\
\hline & 3.5 & 4.0 \\
\hline Ground corn & 65.41 & 64.98 \\
\hline Soybean meal & 20.24 & 20.84 \\
\hline Wheat bran & 3.66 & 2.23 \\
\hline Dicalcium phosphate & 1.29 & 1.31 \\
\hline Soybean soapstock & 1.00 & 1.00 \\
\hline Calcitic limestone & 7.73 & 8.97 \\
\hline Mineral supplement* & 0.10 & 0.10 \\
\hline Vitamin supplement** & 0.10 & 0.10 \\
\hline Salt & 0.35 & 0.35 \\
\hline DL-Methionine & 0.12 & 0.12 \\
\hline Total & 100.00 & 100.00 \\
\hline \multicolumn{3}{|l|}{ Calculated composition } \\
\hline ME (kcal/kg feed) & 2790 & 2790 \\
\hline Crude protein (\%) & 15.5 & 15.5 \\
\hline Calcium (\%) & 3.5 & 4.0 \\
\hline Available phosphorus (\%) & 0.34 & 0.34 \\
\hline Methionine (\%) & 0.35 & 0.35 \\
\hline Methionine+cystine (\%) & 0.64 & 0.64 \\
\hline Lysine (\%) & 0.74 & 0.74 \\
\hline \multicolumn{3}{|c|}{$\begin{array}{l}\text { * Mineral supplementation per } \mathrm{kg} \text { feed: zinc } 54 \mathrm{mg} \text {, iron } 54 \mathrm{mg} \text {, } \\
\text { manganese } 72 \mathrm{mg} \text {, copper } 10 \mathrm{mg} \text {, iodine } 0.61 \mathrm{mg} \text {, selenium } 0.302 \mathrm{mg} \text {. } \\
* * \text { Vitamin supplement per } \mathrm{kg} \text { feed: Vit A } 7,520 \mathrm{IU} \text {, Vit D3 } 1,816 \mathrm{IU} \text {, } \\
\text { Vit E } 8.4 \mathrm{mg} \text {, Vit K3 } 1.28 \mathrm{mg} \text {, Vit B1 } 1.34 \mathrm{mg} \text {, Vit B2 } 3.0 \mathrm{mg} \text {, Vit B6 } \\
1.66 \mathrm{mg} \text {, Vit B12 } 8.0 \mathrm{mcg} \text {, nicotinic acid } 20 \mathrm{mg} \text {, calcium pantothenate } \\
8.0 \mathrm{mg} \text {, folic acid } 0.300 \mathrm{mg} \text {, biotin } 0.04 \mathrm{mg} \text {. }\end{array}$} \\
\hline
\end{tabular}

After forced molting, were submitted to equal management and feeding conditions until the peak of production, when they were standardized according to body weight and egg production.

The experiment started 60 days after the beginning of molting, when birds had reached $50 \%$ of production. Layers were 83 weeks of age at the beginning of the experiment and 111 weeks of age at the end.

Limestone particle size was analyzed according to the method described by Zanotto \& Bellaver (1996). A duly identified sample consisting of approximately $1 \mathrm{~kg}$ of each limestone source was used to determine particle size using a vibrator with ABNT sieves numbers $5,10,16,30,50,100$, and bottom, corresponding to the following mesh openings $(\mathrm{mm}): 4,2,1.20,0.60$, $0.30,0.15$ and bottom.

Particle size was characterized according to treatment and particle geometric standard deviation, expressed as mean geometric diameter (MGD).
In-vitro solubility was determined according to the method described by Cheng \& Coon (1990b) of the University of Minnesota (weight loss percentage method). A $400 \mathrm{~mL}$ beaker, containing $100 \mathrm{~mL}$ of a $\mathrm{HCl}$ solution at $0.1 \mathrm{M}(8.35 \mathrm{~mL} \mathrm{HCl} / \mathrm{L}$ water), was heated for 15 minutes in an oven at $42^{\circ} \mathrm{C}$, with shaking at $60 \mathrm{rpm}$. Two grams of limestone were placed in the beaker, and allowed to react for 10 minutes. The beaker content was then filtered through a "Whatman 42 " paper filter, which was previously dried in an oven and weighed, and then the beaker and the limestone residues were washed with deionized water. Filters and samples were dried at $55^{\circ} \mathrm{C}$ for 12 hours, and weighed. The percentage of solubilized limestone was calculated as the difference between initial and final weight, and expressed as in-vitro limestone solubility percentage. The different limestone sources were submitted to calcium chemical composition analysis using EDTA chelatometric method (Brasil, 1988).

Layers were distributed in a completely randomized experimental design in a $2 \times 3$ factorial arrangement with six treatments: two dietary calcium levels $(3.5 \%$ or $4.0 \%)$ and three limestone particle size compositions, as follows: $100 \%$ fine limestone $(0.185 \mathrm{~mm}), 30 \%$ coarse limestone $(2.83 \mathrm{~mm})+70 \%$ fine limestone $(0.185 \mathrm{~mm})$, or $50 \%$ coarse limestone $(2.83 \mathrm{~mm})+50 \%$ fine limestone $(0.185 \mathrm{~mm})$. There were six replicates per treatment of eight birds each, totaling 288 birds in 36 experimental cages.

The following treatments were applied: $3.5 \%$ calcium with $100 \%$ fine particle limestone (T1), 3.5\% calcium with $70 \%$ fine particle limestone and 30\% coarse particle limestone (T2); $3.5 \%$ calcium with $50 \%$ fine particle limestone and $50 \%$ coarse particle limestone (T3); $4.0 \%$ calcium with 100\% fine particle limestone (T4), $4.0 \%$ calcium with $70 \%$ fine particle limestone and 30\% coarse particle limestone (T5); 4.0\% calcium with $50 \%$ fine particle limestone and $50 \%$ coarse particle limestone (T6).

Eggs from each experimental unit were daily collected and counted to determine egg production. Eggs and feed residues were weekly weighed for performance evaluation. The following parameters were evaluated: egg weight $(\mathrm{g})$, egg production (\%), egg mass (\%), feed intake (g), feed conversion ratio $(\mathrm{kg} / \mathrm{dz}$ and $\mathrm{kg} / \mathrm{kg})$, and mortality. An experimental period of 112 days was considered.

Egg quality was measured at the end of four 28day periods, collecting four eggs from each init for three consecutive days, totaling 72 eggs per treatment. Eggs were identified per treatment and individually weighed 


\section{Pizzolante CC, Saldanha ESPB, Laganá C, Kakimoto SK, Togashi CK}

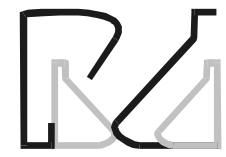

in a digital scale with $0.001 \mathrm{~g}$ precision. Eggs were then submitted to the laboratory to determine specific gravity; yolk, albumen, and eggshell percentages, yolk index $(\mathrm{YI})$, Haugh units $(\mathrm{HU})$, eggshell thickness (ET), and eggshell breaking strength (BS).

Specific gravity was determined by immersing eggs in saline solutions with densities between 1,065 and $1,100 \mathrm{~g} / \mathrm{cm}^{3}$, in 0.005 gradients.

Eggs were then broken, and eggshell, albumen, and yolk were separated and weighed.

Eggshells were rinsed running water and dried in a force-ventilation oven at $60^{\circ} \mathrm{C}$ for $12 \mathrm{~h}$, to determine eggshell thickness (including the membrane) in three points of the egg equatorial region using a Mitutoyo caliper with a $0.01 \mathrm{~mm}$ precision. Eggshells were weighed using a $0.001 \mathrm{~g}$ precision scale.

Albumen quality was evaluated in Haugh units. Using egg weight $(\mathrm{g})$ and albumen height $(\mathrm{mm})$ data, Haugh units were determined according to the formula suggested by Standelman \& Cotterill (1986): HU= 100 $\log \left(H+7.57\right.$ - 1.7W $\left.W^{0.37}\right)$, where: $\mathrm{HU}=$ Haugh unit; $\mathrm{H}=$ albumen height $(\mathrm{mm})$, and $\mathrm{W}=$ egg weight $(\mathrm{g})$.

Yolk quality was expressed in yolk index. Yolk height and diameter were measured, and their ratio determined yolk index, according to the formula: $\mathrm{YI}=$ $\mathrm{YH} / \mathrm{YD}$, where $\mathrm{YI}=$ yolk index, $\mathrm{YH}=$ yolk height $(\mathrm{mm})$, and $Y D=$ yolk diameter $(\mathrm{mm})$.

Eggshell breaking strength was evaluated in intact whole eggs using a specific cell coupled to a Texture Analyser TA. XT plus apparatus with a Cyl Stainless $2 \mathrm{~mm}$ probe, code $\mathrm{P} / 2$, pre-test velocity of $2 \mathrm{~mm} / \mathrm{sec}$, test velocity of $1.0 \mathrm{~mm} / \mathrm{sec}$, and post-test velocity of $40 \mathrm{~mm} / \mathrm{sec}$, recording the strength required to break the eggshell, expressed in kgf.

Data were submitted to analysis of variance, and treatment means were compared by the test of Tukey at $5 \%$ significance using SISVAR software package (Ferreira, 2000).

\section{RESULTS AND DISCUSSION}

Average minimum and maximum temperatures recorded during the experimental period were 18 and $29^{\circ} \mathrm{C}$, with average temperature of $22.3^{\circ} \mathrm{C}$.

The results of the analyses to determine limestone particle size, in-vitro solubility and calcium content are shown in Table 2.

The analysis of variance did not detect significant treatment effects on any of the evaluated performance parameters. There were no statistical differences between calcium levels or among limestone particle
Effects of Calcium Levels and Limestone Particle Size on The Egg Quality of Semi-Heavy Layers in Their Second Production Cycle size compositions, as well as no interactions among these two factors. The following means were determined: egg weight $=68.88 \mathrm{~g}(\mathrm{CV}=2.15 \%)$; egg production $=85.91 \%(C V=4.99 \%)$; egg mass $=59.14 \mathrm{~g}$ $(C V=5.02 \%)$; average daily feed intake $=111.08 \mathrm{~g}$ $(\mathrm{CV}=2.69 \%)$; feed conversion ratio per dozen eggs = $1.56(C V=4.09 \%)$, feed conversion ratio per $\mathrm{kg}$ eggs $=1.90(\mathrm{CV}=3.97 \%)$, mortality $=2.99 \%(\mathrm{CV}=$ $175.94 \%)$, and egg loss $=0.74(C V=34.14 \%)$.

\begin{tabular}{lccc}
\hline \multicolumn{4}{l}{ Table $\mathbf{2}$ - Limestone particle size composition, in-vitro solubility } \\
and calcium content. \\
\hline Limestone & $\begin{array}{c}\text { Particle } \mathbf{s i z e} \\
\text { or MGD }(\mathbf{m m})\end{array}$ & $\begin{array}{c}\text { In-vitro } \\
\text { solubility }(\%)\end{array}$ & $\begin{array}{c}\text { Calcium } \\
\mathbf{( \% )}\end{array}$ \\
\hline Fine & 0.185 & 18.7 & 35.7 \\
Coarse & 2.83 & 10.5 & 36.4 \\
\hline
\end{tabular}

MGD = mean geometric diameter .

These results are consistent with the findings of Zhang \& Coon (1992), Murata (1995), Oliveira et al. (1995), and Scheideler (1998) for feed intake and egg weight. Cheng \& Coon (1990c) and Café et al. (1999) evaluated the effect of limestone source and particle size and did find any significant differences on feed conversion ratio.

We expected that eggs from layers fed coarse limestone presented lower egg loss percentage as compared to those fed fine limestone due to its lower solubility. Despite the lack of significant results, coarse limestone produced less cracked eggs, in absolute values, for the total experimental period. However, the lack of statistical difference may be due to the observed coefficients of variation.

Costa et al. (2008) did not observe significant influence of dietary calcium levels $(3.0,3.4,3.8,4.2$, 4.6, and $5.0 \%$ ) fed to semi-heavy layers after the peak of lay on any of the evaluated performance parameters.

Mean egg quality results, as a function of calcium levels and limestone particle size, are shown in Table 3.

The analysis of variance did not detect any effect ( $p>0.05$ ) of the treatments on any of the evaluated parameters.

Mean egg specific gravity values obtained in the present study was 1.088 , which is consisted with the expected values higher than 1.074 (Junqueira, 1993) and between 1.080 and 1.088 (Mendonça Jr., 1993). The thinner the eggshell, the lower the specific gravity, and therefore, the higher the probability of cracked and broken eggs (Miles, 1993). As layers age, egg size 


\section{Pizzolante CC, Saldanha ESPB, Laganá C, Kakimoto SK, Togashi CK}

\begin{tabular}{|c|c|c|c|c|c|}
\hline \multirow[b]{2}{*}{ Parameters } & \multicolumn{4}{|c|}{ Particle size composition } & \multirow[b]{2}{*}{ CV (\%) } \\
\hline & Calcium levels & $100 \% \mathrm{FL}^{*}$ & $30 \% \mathrm{FL}+70 \% \mathrm{CL}^{* *}$ & $50 \% \quad \mathrm{FL}+50 \% \mathrm{CL}$ & \\
\hline $\begin{array}{l}\text { Specific } \\
\text { gravity } \\
\left(\mathrm{g} / \mathrm{cm}^{3}\right)\end{array}$ & $\begin{array}{c}3.5 \\
4.0 \\
\text { Mean }\end{array}$ & $\begin{array}{l}1.088 \\
1.089 \\
1.088\end{array}$ & $\begin{array}{l}1.088 \\
1.087 \\
1.088\end{array}$ & $\begin{array}{l}1.088 \\
1.088 \\
1.088\end{array}$ & 0.18 \\
\hline $\begin{array}{l}\text { Yolk } \\
(\%)\end{array}$ & $\begin{array}{c}3.5 \\
4.0 \\
\text { Mean }\end{array}$ & $\begin{array}{l}24.18 \\
24.27 \\
24.23\end{array}$ & $\begin{array}{l}24.02 \\
24.33 \\
24.17\end{array}$ & $\begin{array}{l}24.52 \\
24.38 \\
24.45\end{array}$ & 3.57 \\
\hline $\begin{array}{l}\text { Albumen } \\
(\%)\end{array}$ & $\begin{array}{c}3.5 \\
4.0 \\
\text { Mean }\end{array}$ & $\begin{array}{l}66.47 \\
66.16 \\
66.31\end{array}$ & $\begin{array}{l}66.56 \\
66.24 \\
66.40\end{array}$ & $\begin{array}{l}65.97 \\
66.21 \\
66.09\end{array}$ & 1.43 \\
\hline $\begin{array}{l}\text { Eggshell } \\
(\%)\end{array}$ & $\begin{array}{c}3.5 \\
4.0 \\
\text { Mean }\end{array}$ & $\begin{array}{l}9.36 \\
9.57 \\
9.46\end{array}$ & $\begin{array}{l}9.43 \\
9.43 \\
9.43\end{array}$ & $\begin{array}{l}9.50 \\
9.41 \\
9.46\end{array}$ & 3.41 \\
\hline $\begin{array}{l}\text { Yolk } \\
\text { index }\end{array}$ & $\begin{array}{c}3.5 \\
4.0 \\
\text { Mean }\end{array}$ & $\begin{array}{l}0.45 \\
0.45 \\
0.45\end{array}$ & $\begin{array}{l}0.45 \\
0.45 \\
0.45\end{array}$ & $\begin{array}{l}0.45 \\
0.45 \\
0.45\end{array}$ & 1.79 \\
\hline $\begin{array}{l}\text { Haugh } \\
\text { unit }\end{array}$ & $\begin{array}{c}3.5 \\
4.0 \\
\text { Mean }\end{array}$ & $\begin{array}{l}82.41 \\
81.02 \\
81.71\end{array}$ & $\begin{array}{l}83.64 \\
81.57 \\
82.61\end{array}$ & $\begin{array}{l}81.19 \\
83.49 \\
82.34\end{array}$ & 4.03 \\
\hline $\begin{array}{l}\text { Eggshell } \\
\text { thickness } \\
(\mathrm{mm})\end{array}$ & $\begin{array}{c}3.5 \\
4.0 \\
\text { Mean }\end{array}$ & $\begin{array}{l}0.41 \\
0.41 \\
0.41\end{array}$ & $\begin{array}{l}0.41 \\
0.41 \\
0.41\end{array}$ & $\begin{array}{l}0.41 \\
0.41 \\
0.41\end{array}$ & 3.04 \\
\hline $\begin{array}{l}\text { Eggshell } \\
\text { breaking strength } \\
\text { (kgf) }\end{array}$ & $\begin{array}{c}3.5 \\
4.0 \\
\text { Mean }\end{array}$ & $\begin{array}{l}2.90 \\
3.01 \\
2.96\end{array}$ & $\begin{array}{l}2.67 \\
2.91 \\
2.79\end{array}$ & $\begin{array}{l}2.94 \\
2.92 \\
2.93\end{array}$ & 6.74 \\
\hline
\end{tabular}

$F L^{*}=$ fine limestone; $C L^{* *}=$ coarse limestone.

increases, eggshell thickness decreases, and consequently specific gravity is reduced, indicating a direct relation between eggshell thickness and the remaining egg components (Mendonça Jr., 1993).

The results of the present study are consistent with those obtained by Keshavarz \& Nakajima (1993), who worked with different dietary calcium levels and did not find egg specific gravity differences when calcium level was increased from $3.5 \%$ to $4.0 \%$. Kussakawa et al. (1998) also did not detect any influence on egg specific gravity of $0.25-0.50 \mathrm{~mm}$ fine limestone or 1.00 $2.38 \mathrm{~mm}$ coarse limestone.

There were no qualitative losses in terms of eggshell percentage or thickness. It was expected that the tested calcium levels and the supplied coarse limestone provided more calcium available for eggshell formation due to the longer retention of limestone in the gizzard, as suggested by Rao \& Roland (1990) and Miles (2000). However, the results show that the treatments used provided sufficient calcium for efficient eggshell deposit, independent of calcium levels and limestone particle size. Murata (1995), evaluating calcium levels $(3.75,4.15$, and $4.55 \%)$ and different rates $(0,25,50$, 75 , and $100 \%$ ) of powdered limestone replacement by granulated limestone in the feed of 57-week-old layers, also did not detect any influence of the treatments on egg production, egg loss percentage, egg weight, eggshell breaking strength, percentage and thickness, as well as egg apparent density. In the study of Kussakawa et al. (1998), there was no significant influence on eggshell weight when fine limestone (particle size of $0.25-0.50 \mathrm{~mm}$ ) or coarse limestone (particle size of $1.00-2.38 \mathrm{~mm}$ ) were fed. Scheideler (1998), quoted by Jardim Filho et al. (2005b) reported that layers are able to solubilized calcium consumed in large particles as compared to low particles, consequently retaining more calcium. Therefore, at the time of eggshell formation, blood calcium concentration is higher, and the body uses less bone deposits, allowing higher calcium use for eggshell formation.

Bertechini (2006) explained that after calcium is ingested, it is absorbed to the blood, where it is present as free calcium or bound to the calcium-transporting protein, calmodulin. This complex functions as plasmatic storage, and it is highly available to be ionized as free calcium is used for eggshell formation. The surplus of ingested calcium is deposited in structural or medullar 


\section{Pizzolante CC, Saldanha ESPB, Laganá C, Kakimoto SK, Togashi CK}

Effects of Calcium Levels and Limestone Particle Size on The Egg Quality of Semi-Heavy Layers in Their Second Production Cycle bones, which consist of less labile storage sites, but not less important, particularly as eggshell formation occurs during the dark period, when birds do not consume feed.

Rodrigues et al. (2005) supplied 2.0 and $3.5 \%$ calcium to light commercial layers in their second laying cycle, and observed better external egg quality results with the higher calcium level. This is consistent with the present experiment, where $3.5 \%$ calcium supplied by fine limestone, as typically recommended for white layers in their first laying cycle, maintained egg quality during the second laying cycle.

Roland \& Bryant (1994) reported a linear increase in egg specific weight when dietary calcium levels were increased from 2.5 to $4.5 \%$, which was different from the present study, which did not detect any influence of calcium levels.

Costa et al. (2008) supplied different calcium levels $(3.0,3.4,3.8,4.2,4.6,5.0 \%)$ to semi-heavy layers after the peak of lay and found that increasing dietary calcium levels increased albumen and eggshell percentages relative to the other egg components. Those authors recommend a level of $4.3 \%$ calcium for semi-heavy layers after the peak of lay.

Geraldo et al. (2006) did not observe any effect of limestone particle size on egg specific weight, whereas Hamilton et al. (1985), Cheng \& Coon (1990c), and Ito et al. (2006) showed that coarse limestone increased egg specific weight as compared fine limestone.

Jardim Filho et al. (2005a) observed better eggshell quality in layers fed limestone as grit (MGD range of 2.0-5.0 $\mathrm{mm}$ ) as compared to those fed fine (MGD<1.0 $\mathrm{mm}$ ) and medium (MGD range of $<1.0-1.0 \mathrm{~mm}$ ) limestone. Guinotte \& Nys (1991) found higher eggshell strength, egg weight, and eggshell weight when feeding large-particle calcium sources. The authors attributed the results to higher calcium retention in the crop and gizzard.

Roland et al. (1978) worked with calcium-deficient diets, and concluded that the decline in eggshell quality in older layers are not due to a reduction in their capacity to efficiently absorb or utilize skeletal calcium, but rather because calcium retention remains constant, and their eggs are larger as compared to those of younger layers.

Large particles may be beneficial in situations that cause reduction in calcium intake or availability (Rao et al., 1992). The partial substitution of fine limestone by coarse limestone in the present study may not have promoted any improvement in eggshell quality because layers were offered ad libitum water and feed containing correct nutritional levels, were free of diseases, and submitted to a lighting program that probably promoted bird welfare and absence of stress.

Our results are also consistent with those obtained by Rodrigues (1995), who observed that internal egg quality of second-cycle layers, as evaluated by Haugh units, specific weight, and average eggshell thickness, was not influenced by dietary calcium levels (3.8 vs. $4.5 \%)$, independent of production stage. However, in a previous study, Rodrigues et al. (1994) applied two calcium levels (3.8 and 4.2\%), and observed better Haugh units in the second laying cycle when the highest calcium level was fed.

\section{CONCLUSIONS}

Under the conditions of the present experiment, we concluded that neither dietary calcium level or limestone particle size had any influence on egg quality of second-laying cycle layers.

The 3.5\% calcium level recommended for first-laying cycle light layers can be fed to commercial Hy-Line Brown semi-heavy layers in second laying cycle.

Limestone in fine particle size can be substituted in up to $50 \%$ by limestone in coarse particle size with no detrimental effect on egg quality.

\section{REFERENCES}

Bertechini AG. Nutrição de monogástricos. Lavras (MG): Lavras; 2006. 302 p.

Bertechini AG, Fassani EJ. Macro e microminerais na alimentação animal. Anais do $1^{\circ}$ Simpósio Sobre Ingredientes na Alimentação Animal; 2001; Campinas, São Paulo. Brasil. Campinas: CBNA; 2001. p. 219-234.

Borges ALCC. Controle da ingestão de alimentos. Cadernos Técnicos da Escola de Veterinária da UFMG 1999; 27:67-79.

Brasil. Ministério da Agricultura. Secretaria Nacional de Defesa Agropecuária, Análises de corretivos, fertilizantes e inoculantes métodos oficiais. Brasília (DF): Laboratório Nacional de Referência Vegetal; 1988. 104p.

Café MB. et al. Influência da particle size da fonte calcium na produção e qualidade de ovos de poedeiras comerciais. Anais do $1{ }^{\circ}$ Congresso de Produção e Consumo de Ovos; 1999; São Paulo, SP. Brasil. São Paulo: APA; 1999. p. 119-20.

Cheng TK, Coon CN. Effect of calcium source, particle size, limestone solubility in vitro, and calcium intake level on layer bone status and performance. Poultry Science 1990a; 69(12):2214-2219.

Cheng TK, Coon CN. Comparision of various in vitro methods for 


\section{Pizzolante CC, Saldanha ESPB, Laganá C, Kakimoto SK, Togashi CK}

the determination of limestone solubility. Poultry Science 1990b; 69(12):2204-2208.

Cheng TK, Coon CN. Effect on layer performance and shell quality of switching limestones with different solubilites. Poultry Science 1990c; 69(12):2199-2203.

Costa FGP, Oliveira FLS, Dourado LRB, Lima Neto RC, Campos MASF, Lima AGVO. Níveis calcium em dietas para poedeiras semipesadas após o pico de postura. Revista Brasileira de Zootecnia 2008; 37(4):624-628.

Elaroussi $A E$, Forte LR, Eber SL, Bieller HV. Calcium homeostasis in the laying hen. 1. Age and dietary calcium effects. Poultry Science 1994; 73(10):1581-89.

Faria DE, Junqueira OM, Sakomura NK, Santana AE. Sistemas de alimentação e suplementação de farinha de casca de ostras sobre o desempenho e a qualidade da casca dos ovos de poedeiras comerciais. Revista Brasileira de Zootecnia 2000; 29(5):1394-1401.

Ferreira DF. Sistema para análise de variância para dados balanceados (SISVAR). Lavras (MG): UFLA; 2000. 92 p.

Geraldo A, Bertechini AG, Kato RK, Brito JAG, Fassani EJ. Níveis calcium e particle size do limestone para frangas e seus efeitos sobre a produção e qualidade de ovos. Revista Brasileira de Zootecnia 2006; 35(4):1720-1727.

Guinotte F, Nys Y. Effects of particle size and origin of calcium sources on eggshell quality and bone mineralization in laying hens. Poultry Science 1991; 70:583-592.

Hamilton RMG, Fairfll RW, Gowe RS. Use of particulate limestone or oyster shell in dietary regimens of White Leghorn hens. Poultry Science 1985; (64):1750-1762.

Ito DT. Efeito do fracionamento calcium e particle size do limestone sobre o desempenho e qualidade de ovos de poedeiras comerciais. Acta Scientiarum Animal Science 2006; 28(2):187-195.

Ito DT. Efeito do fracionamento calcium e particle size do limestone sobre o desempenho e qualidade de ovos de poedeiras brancas [mestrado]. Pirassununga (SP): Universidade de São Paulo; 2002.

Jardim Filho RM, Stringhini JH, Café MB, Andrade MA, Sakamoto MI, Franco JRG. Influência das fontes e particle size do limestone calcítico sobre a densidade, resistência e composição mineral da tíbia de poedeiras comerciais. Acta Scientiarum. Animal Sciences 2005b; 27(1):23-28.

Jardim Filho RM, Stringhini JH, Café MB, Leandro NSM, Cunha WCP, Nascimento Jr O. Influência das fontes e particle size do limestone calcítico sobre o desempenho e a qualidade da casca dos ovos de poedeiras comerciais. Acta Scientiarum. Animal Sciences 2005a; 27(1):35-41.

Junqueira OM. Avanços recentes nas exigências de fósforo para poedeiras. Anais da Conferência Apinco 1993 de Ciência e Tecnologia Avícolas; 1993; Santos, São Paulo. Brasil. Santos: FACTA; 1993. p.167-175.
Keshavarz K, Nakajima S. Re-evaluation of calcium and phosphorus requeriments of laying hens for optimum performance and eggshell quality. Poultry Science 1993; 72(1):144-153.

Kussakawa KCK, Murakami AE, Furlan AC. Combinações de fontes calcium em rações de poedeiras na fase final de produção e após muda forçada. Revista Brasileira de Zootecnia 1998; 27(3):572578.

Leeson S, Summers JD. Commercial poultry nutrition. 2nd ed. Guelph: University Books; 1997. 355p.

Mazzuco H, Hester PY. The effect of an induced molt and a second cycle of lay on skeletal integrity of White Leghorns. Poultry Science 2005; 84:771- 781.

Mendonça Júnior CX. Fatores nutricionais envolvidos na qualidade do ovo. Anais do $3^{\circ}$ Simpósio Tecnico de Produção de ovos; 1993; São Paulo, SP. Brasil. São Paulo: APA; 1993. p.29-51.

Miles R. Fatores nutricionais relacionados a qualidade da casca dos ovos. Anais do Simpósio Goiano de Avicultura; 2000; Goiânia, Goiás. Brasil. Goiânia: UFGO; 2000. p.173-195.

Miles RD. Gravedad específica del huevo-establecimento de un programa de verificación. Generalidades sobre la calidad del cascarón de huevo. México: Associación Americana de Soya, 1993. p. 1-8.

Murata LS. Particle size do calcario e niveis de calcio na qualidade da casca de ovos de poedeiras comerciais [dissertação]. Jaboticabal (SP): Universidade Estadual Paulista; 1995.

Oliveira JR, Bertechini AG, Fassani EJ. Níveis calcium em dietas para poedeiras leves e semipesadas no segundo ciclo de produção. Ciência e Agrotecnologia 2002; 26:1060-1067.

Rao KS, Roland SR, Adams JL. Improved limestone retention in gizzard of commercial leghorn hens. Journal Applied Poultry Research 1992; 1(1):6-10.

Rao KS, Roland SR. In vivo limestone solubilization in commercial Leghorns: role of dietary calcium level, limestone particle size, in vitro limestone solubility rate, and the calcium status of the hen. Poultry Science 1990; 69:2170-2176.

Rodrigues EA, Junqueira OM, Valério M, Andreotti MO, Cancherini LC, Faria DE, Filardi RS. Níveis calcium em rações de poedeiras comerciais no segundo ciclo de postura. Acta Scientiarum. Animal Sciences 2005; 27(1):49-54.

Rodrigues PB, Bertechini AG, Oliveira BL. Estudo de fatores que afetam o desempenho e a qualidade do ovo de poedeiras comerciais no $2^{\circ}$ ciclo. Anais da Conferência Apinco 1994 de Ciência e Tecnologia Avícolas; 1994; Campinas, São Paulo. Brasil. Campinas: FACTA; 1994. p.45-46.

Rodrigues PB. Fatores nutricionais que influenciam a qualidade do ovo no segundo ciclo de produção [mestrado]. Lavras (MG): Universidade Federal de Lavras; 1995.

Roland DA, Putman CE, Hilburn RL. The relationship of on ability of 
hens to maintain eggshell calcification when stressed with adequate dietary calcium. Poultry Science 1978; 57(6):1616-1621.

Roland DA. Efecto del momento de la ingestion calcium sobre la calidad de la cascara. Avicultura Profesional 1984; 2(1):31-32.

Roland DA. Eggshell quality. IV - Oystershell versus limestone and the importance of particle size or solubility of calcium source. World's Poultry Science Journal 1986; 42(2):166-71.

Roland DA, Bryant M. Influence of calcium on energy consumption and egg weight of commercial Leghorns. Journal Applied Poutry Research 1994; 3(2):184-189.

Rostagno HS, Albino LFT, Donzele JL, Gomes PC, Ferreira AS, Oliveira RF. Composição de alimentos e exigências nutricionais de aves e suínos: tabelas brasileiras para aves e suínos. Viçosa (MG): UFV; 2000.

Scheideler SE. Eggshell calcium effects on egg quality and calcium digestibility in first or third cycle laying hens. Journal Applied Poutry Research 1998; 7:69-74.

Standelman WJ, Cotterill OJ. Egg science and technology. 3rd ed. New York: Food Products Press; 1986. 499 p.

Swanson ML, Johnson G. Eggshell damage during handling. Poultry Digest 1973; 32(371):12-13.

Swenson MJ, Reece WO. Dukes: fisiologia dos animais domésticos. 11 nd ed. Guanabara Koogan: Rio de Janeiro; 1996. 856p.

Zanotto DL, Bellaver C. Método de determinação da particle size de ingredientes para uso em rações de suínos e aves. Concórdia: EMBRAPA, 1996 [Comunicado Técnico 215].

Zhang B, Coon CN. Calcium solubility in feed formulation for laying hens. Minnesota: Nutrition Institute, University of Minnesota; 1992. p. 1-10. 